Gut, 1969, 10, 796-799

\title{
Secretory response to secretin in a patient with diarrhoea and the Zollinger-Ellison pattern of gastric secretion
}

\author{
H. PETERSEN, J. MYREN, AND I. LIAVÅG \\ From the Laboratory of Gastroenterology, Medical Department IX and Surgical Department II, \\ Ullevål Hospital, Oslo, Norway
}

SUMMARY In a woman with diarrhoea and the Zollinger-Ellison pattern of gastric secretion, the secretion of fluid and bicarbonate into the duodenum in response to secretin was found to be significantly greater than in controls. No pancreatic tumour was found at operation. The pancreas was, however, larger than normal.

The patient did not show symptoms of peptic ulcer disease until vagotomy and pyloroplasty had been performed. A capacity to secrete large amounts of bicarbonate was believed to be the explanation of why she was able to tolerate great amounts of acid.

Little attention has been paid to the exocrine pancreatic function in the Zollinger-Ellison syndrome. Decreased enzymatic activity in unstimulated duodenal aspirates has been found by some authors (Maynard and Point, 1958; Summerskill, 1959) and normal by others (Rawson, England, Gillam, French, and Stammers, 1960; Donaldson, Vom Eigen, and Dwight, 1957). After stimulation with secretin and pancreozymin both normal (Shay, Chey, Koide, and Burnett, 1962) and decreased responses (Summerskill, 1959) have been reported. A recent report dealing with the response to a test meal in two patients with the Zollinger-Ellison syndrome (Cook and French, 1968) demonstrates that the amount of alkalinity and activity of trypsin in the upper small intestine may show great variations.

\section{CASE REPORT}

A 37-year-old married woman had diarrhoea for the first time in 1964. She had never had dyspepsia before or other complaints indicating any disorder, including endocrine disease. The diarrhoea progressed and in 1966 when we saw her for the first time, she was passing five to 10 loose stools daily which often were bulky and greyish in colour, suspicious of steatorrhoea. She had no dyspepsia or weight loss and her appetite was good. During the next two years the diarrhoea progressed moderately but the patient had no other complaints. A temporary improvement was achieved during treatment with an anticholinergic drug, oxyphencyclimine $\mathrm{HCl}^{1}$

${ }^{1}$ Daricon, Pfizer.
LABORATORY FINDINGS The physical examination of the patient was unremarkable. Her body weight was $65 \mathrm{~kg}$ and her height $167 \mathrm{~cm}$. Blood examination showed normal values for concentrations of haemoglobin, protein, iron, cholesterol, urea, and creatinine. The sedimentation rate was $1 \mathrm{~mm} / \mathrm{hr}$ and the red and white blood cell counts were within normal limits. Glucose tolerance tests performed in 1967 and 1968 were normal and normal values were obtained for the blood concentrations of alkaline phosphatase, glutamic oxalic transaminase, total bilirubin and prothrombin, and for bromsulphalein by the retention test. The serum concentrations of electrolytes, including potassium, were normal.

Absorption studies Stool fat excretion was raised on a standard ward diet containing approximately $100 \mathrm{~g}$ fat daily. The absorption of vitamin A was decreased, being $582 \mathrm{IU} / 100 \mathrm{ml}$ in 1968, a slight improvement over the values for earlier reports. Two of three D-xylose tests were abnormal. In 1967 the result for D-xylose tests was $3.7 \mathrm{~g}$ in five-hour urine and in 1968 it had fallen to $3.4 \mathrm{~g}$.

Radiology Coarse and prominent mucosal folds in the stomach were demonstrated in 1966 and in February and May 1968. In the duodenum the contrast medium showed an irregular pattern suggesting an oedematous and hypertrophic mucosa, but no ulceration was observed. Cineradiology repeatedly demonstrated a very rapid transit time of the barium meal through the small intestine. Nothing pathological was found on $x$-ray examination of the colon or by rectoscopy. Pancreatic scanning with selenomethionine $\left({ }^{75} \mathrm{Se}\right)$ and radiographic examination after retroperitoneal air insufflation were inconclusive. Aortography did not demonstrate anything pathological.

Biopsy studies A gastric biopsy obtained by a Crosby 
capsule showed a normal corpus and pyloric mucosa, whereas a small bowel biopsy demonstrated moderate mucosal abnormalities with partial villous atrophy and moderate infiltration with lymphocytes and plasma cells.

Gastric secretion Gastric secretion was examined by the augmented histamine test (Kay, 1953) using $0.05 \mathrm{mg}$ histamine chloride per kilogram body weight as stimulant (Petersen, 1969a). The volumes were determined in millilitres and the amount of acid in milliequivalents by titration electrometrically to $p \mathrm{H} \mathbf{7 \cdot 4}$. Very high basal acid outputs were found compared with those after histamine (Table I).

Pancreatic secretion The secretion of fluid and bicarbonate into the duodenum was examined using the Lagerlöf double-lumen tube (Petersen, 1969a). The gastric and duodenal juices were aspirated continuously for 20 minutes before, and for three 20-minute periods after, intravenous injection of 1 clinical unit of highly purified secretin (Jorpes, 1968) per kilogram body weight. The volumes of gastric and duodenal aspirates were measured in millilitres and the acid in gastric juice and the bicarbonate in duodenal juice, in milliequivalents by titration electrometrically to $p \mathrm{H} \mathrm{7 \cdot 4}$ and by the method of Van Slyke, respectively.

The examinations performed when the patient was not receiving anticholinergic treatment (May 1966, September 1966, and February 1968) showed good agreement. The volumes of duodenal juice aspirated before administration of secretin were significantly greater than in healthy young soldiers who were used as controls (Petersen, 1969b). The basal bicarbonate concentrations, however, were not significantly different from those in controls. After injection of secretin very high values were found for the volumes of duodenal aspirate and for the bicarbonate concentrations as well as for the bicarbonate outputs. The total 60 -minute post-secretin volumes and bicarbonate outputs were significantly higher than in controls and ranged from 450 to $550 \mathrm{ml}$ and from 49.3 to 53.9 m-equiv, respectively. None of the postsecretin samples were bile stained. The amount of fluid and acid aspirated from the stomach was significantly greater than in controls, both before and after injection of secretin. The acid outputs were 57 and 52 m-equiv before secretin when calculated for one hour and 62 and $83 \mathrm{~m}$-equiv in the post-secretin hour.

The examination performed in July 1967 during treatment with oxyphencyclimine $\mathrm{HCl}$ showed a considerable reduction in the amount of fluid and acid aspirated from the stomach both before and after administration of secretin. Although the volumes of duodenal juice aspirated after injection of secretin were almost unchanged, the bicarbonate concentrations and outputs were greatly decreased.

The results of these tests are illustrated in Figures 1 to 3.

The gastric secretion-stimulating effect of plasma was determined in May 1968, in rats at the Western General Hospital, Edinburgh, and no secretagogue effect was demonstrated (Thomson and Sircus, 1967).

OPERATIONS AND FOLLOW UP A laparotomy was performed in June 1968. The pancreas and mesentery were carefully examined and the duodenum was opened. No tumour was found in the pancreas or its vicinity. The body of the pancreas was, however, definitely larger than normal. No duodenal or gastric ulcer was discovered. A selective gastric vagotomy and a Weinberg pyloroplasty were performed.

For the first week after operation the stomach was emptied by suction through a nasogastric tube. The amount of aspirated gastric juice rose to $3.5 \mathrm{l}$. on the fifth postoperative day. After removing the tube the patient suffered from increasing burning epigastric pain which was relieved by food or antacids. A gastric secretory study performed two weeks postoperatively showed an even higher basal acid output than before operation (Table I).

Three weeks postoperatively the patient had increasingly acute abdominal pain and the haemoglobin fell. $X$-ray examination of the stomach and duodenum showed two big ulcers in the second part of the duodenum. Four weeks after the first operation, total gastrectomy and Roux-en-Y reconstruction with end-to-side oesophago-jejunostomy were carried out. The postoperative course was uneventful and the patient left hospital three weeks after the second operation.

During the follow up (six months) her body weight remained constant $(53 \mathrm{~kg})$. She did not complain of dyspepsia or diarrhoea but had to take small and frequent meals.

\section{DISCUSSION}

Our patient repeatedly demonstrated an enormous basal gastric hypersecretion of acid amounting to 50 to $92 \%$ of the histamine-stimulated values. Diarrhoea and malabsorption were the most

TABLE I

GASTRIC SECRETION

\begin{tabular}{|c|c|c|c|c|c|}
\hline \multirow[t]{2}{*}{ Date of Test } & \multicolumn{2}{|l|}{ Before Histamine } & \multicolumn{2}{|l|}{ After Histamine } & \multirow[b]{2}{*}{$\begin{array}{l}B A O / M A O \\
(\%)\end{array}$} \\
\hline & $\begin{array}{l}\text { Volume of Gastric } \\
\text { Secretion }(\mathrm{ml} / \mathrm{hr})\end{array}$ & $\begin{array}{l}\text { Basal Acid Output } \\
\text { (m-equiv/hr) }\end{array}$ & $\begin{array}{l}\text { Volume of Gastric } \\
\text { Secretion }(\mathrm{ml} / \mathrm{hr})\end{array}$ & $\begin{array}{l}\text { Maximal Acid Output } \\
\text { m-equiv/hr) }\end{array}$ & \\
\hline $\begin{array}{l}1966 \\
1968 \text { February } \\
\text { May } \\
\text { Two weeks after }\end{array}$ & $\begin{array}{l}310 \\
466 \\
332\end{array}$ & $\begin{array}{l}16 \\
47 \\
39\end{array}$ & $\begin{array}{l}376 \\
470 \\
456\end{array}$ & $\begin{array}{l}32 \\
64 \\
70\end{array}$ & $\begin{array}{l}50 \\
73 \\
56\end{array}$ \\
\hline $\begin{array}{l}\text { pyloroplasty and } \\
\text { vagotomy }\end{array}$ & 376 & 61 & 378 & 66 & 92 \\
\hline
\end{tabular}



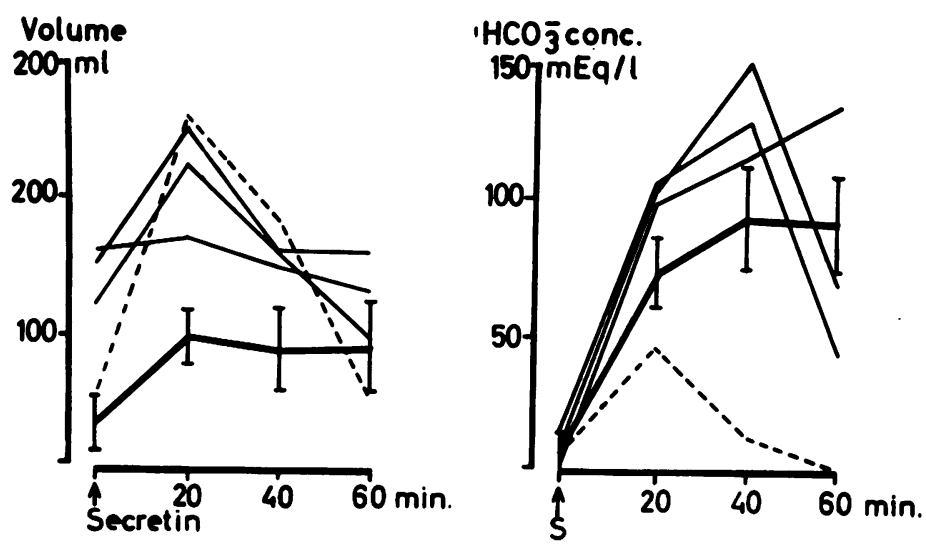

FIG. 1. Values for volume rate and bicarbonate concentration and output of duodenal juice before and after intravenous injection of 1 clinical unit of highly purified secretin per kilogram body weight. Three examinations in patient J.S. without treatment (-) and one examination during treatment with an anticholinergic drug (-- ) (a. cholinerg.) are shown. The results are compared with the mean values and standard deviations for 21 examinations performed in 15 healthy young soldiers (controls).

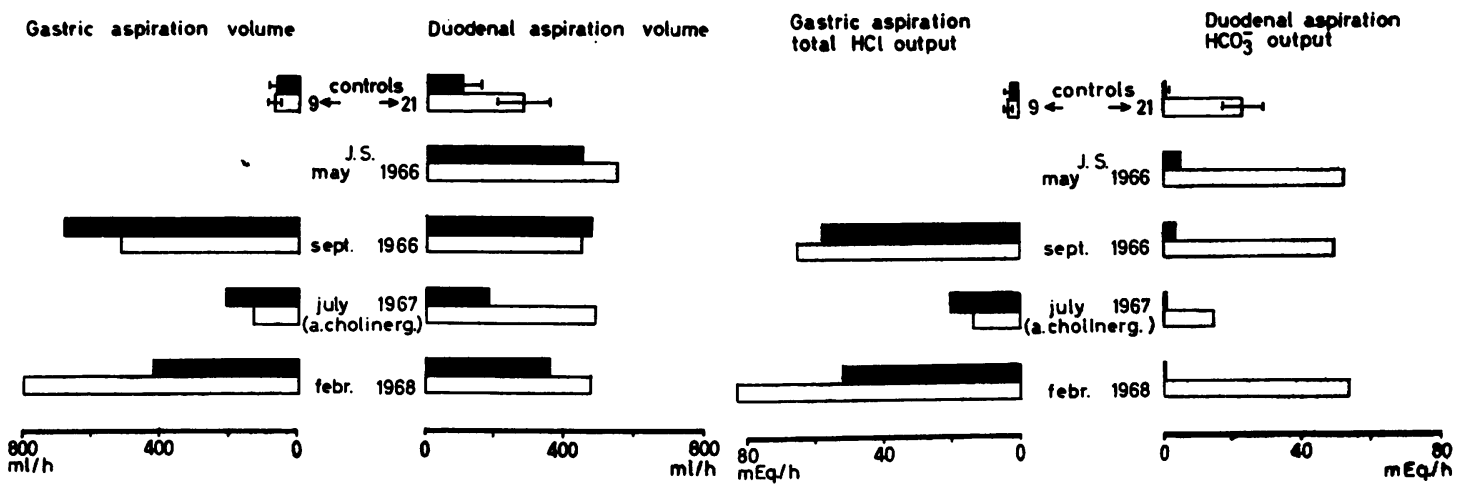

FIG. 2 .

FIG. 3.

FIG. 2. Calculated volumes of duodenal and gastric juice aspirated one hour before and one hour after intravenous injection of 1 clinical unit of highly purified secretin per kilogram body weight. Four examinations in the patient J.S. are compared with the mean values and standard deviations of examinations performed in healthy young soldiers (controls).

FIG. 3. Calculated outputs of bicarbonate and hydrochloric acid per hour in duodenal and gastric juice, respectively, before and after intravenous injection of 1 clinical unit of highly purified secretin per kilogram body weight. Four examinations in the patient J.S. are compared with the mean values and standard deviations for examinations in healthy young soldiers (controls). 
prominent symptoms. A gastrin-producing, nonbeta islet cell tumour was suggested; however, a gastrin effect was not demonstrated in the plasma. Neither the preoperative examinations nor the operations themselves disclosed any tumour in the pancreas or its vicinity. The pancreas was found to be larger than normal.

The unfavourable clinical course of our patient after vagotomy and pyloroplasty provided further support for the diagnosis of a Zollinger-Ellison syndrome, and islet cell hyperplasia still remained the most likely possibility. The marked effect of treatment with the anticholinergic drug on the diarrhoea and on gastric and pancreatic secretion did not preclude the existence of a Zollinger-Ellison syndrome (Vogel, Weinstein, Herskovic, and Spiro, 1967; Shay et al, 1962; Cook and French, 1968).

The secretion of water and bicarbonate into the duodenum was in our patient repeatedly significantly higher than in healthy soldiers. This finding is in agreement with the recently demonstrated positive correlation between bicarbonate secretion following a standard dose of secretin and gastric acid secretin in response to a maximal dose of histamine (Petersen, 1969a). The finding contrasts, however, with earlier studies on the exocrine pancreatic function in the Zollinger-Ellison syndrome demonstrating decreased secretion (Summerskill, 1959; Vogel et al, 1967). On the other hand, there seems to be good agreement between our finding and that of Cook and French (1968), who found an increased acid neutralizing capacity in the small intestine after a test meal in a patient with gastric hypersecretion and islet cell hyperplasia.

Although gastric hypersecretion was enormous our patient did not show symptoms of peptic ulcer disease until vagotomy and pyloroplasty had been performed. The protective effect of the exocrine pancreatic secretion in the experimental production of peptic ulcers is well known (Mann and Williamson, 1923; Poth, Manhoff, and DeLoach, 1948), and recently pentagastrin-induced peptic ulcers in cats have been prevented by giving secretin (Konturek, 1968). Little is known, however, about the significance of the exocrine pancreatic secretory capacity in peptic ulcer pathogenesis in man. The unusual capacity to secrete bicarbonate, repeatedly demonstrated in our patient, may serve as a possible explanation of why she was able to tolerate great amounts of acid.

\section{R EFERENCES}

Cook, H. B. and French, A. B. (1968). Physiologic responses to gastric acid hypersecretion in Zollinger-Ellison syndrome. Amer. J. dig. Dis., 13, 191-203.

Donaldson, R. M., Jr, Vom Eigen, P. R., and Dwight, R. M. (1957) Gastric hypersecretion, peptic ulceration and islet-cell tumour of the pancreas (the Zollinger-Ellison syndrome). New Engl. J. Med., 257, 965-970.

Jorpes, J. E. (1968). The isolation and chemistry of secretin and cholecystokinin. Gastroenterology, 55, 157-164.

Kay, A. W. (1953). Effect of large doses of histamine on gastric secretion of $\mathrm{HCl}$ : an augmented histamine test. Brit. med.J. 2,77-80.

Konturek, S. J. (1968). The effect of secretin on gastric acid secretion and peptic ulcers by pentagastrin in cats with intact or resected duodenum. Amer.J. dig. Dis., 13, 874-881.

Mann, F. C., and Williamson, C. S. (1923). The experimental production of peptic ulcer. Ann. Surg., 77, 409-422.

Maynard, E. P., III, and Point, W. W. (1958). Steatorrhea associated with ulcerogenic tumour of the pancreas. Amer. J. Med., 25, 456-459.

Petersen, H. (1969a). The relationship between gastric and pancreatic secretion in man. Scand. J. Gastroenterol., 4, 345-352.

(1969b). The duodenal aspirate following secretin stimulation. A variance study in man. Ibid, 4, 407-412

Poth, E. J., Manhoff, L. J., Jr, and DeLoach, A. W. (1948). The relation of pancreatic secretion to peptic ulcer formation. Effect of pancreatectomy, ligation of pancreatic ducts, and diabetes on the production of histamine-induced ulcers in the dog. Surgery, 24, 62-69.

Rawson, A. B., England, M. T., Gillam, G. G., French, J. M., and Stammers, F. A. R. (1960). Zollinger-Ellison syndrome with diarrhoea and malabsorption. Lancet, 2, 131-134.

Shay, H., Chey, W. Y., Koide, S. M., and Burnett, W. E. (1962). Mechanism of the disordered physiology involved in the Zollinger-Ellison syndrome. Report of a case. Amer. J. dig. Dis., 7, 401-419.

Summerskill, W. H. J. (1959). Malabsorption and jejunal ulceration due to gastric hypersecretion with pancreatic islet-cell hyperplasia. Lancet, 1, 120-123.

Thomson, C. G., and Sircus, W. (1967). Experiences with a bioassay method for the diagnosis of the Zollinger-Ellison syndrome. (Obstr.) Gut, 8, 632.

Vogel, R. M., Weinstein, L. D., Herskovic, T., and Spiro, H. M. (1967). Mechanisms of steatorrhea in the Zollinger-Ellison syndrome. Ann. intern. Med., 67, 816-822. 